\title{
School Scientific Argumentation Enriched by Digital Technologies: Results With Pre- and in-Service Science Teachers
}

\author{
Leticia Garcia Romano ${ }^{1 *}$, Maricel Occelli ${ }^{1}$, Agustín Adúriz-Bravo ${ }^{2}$ \\ ${ }^{1}$ CONICET - Departamento de Enseñanza de la Ciencia y la Tecnología, Facultad de Ciencias Exactas, Físicas y Naturales, \\ Universidad Nacional de Córdoba, ARGENTINA \\ ${ }^{2}$ CONICET - Universidad de Buenos Aires, Facultad de Ciencias Exactas y Naturales, Instituto de Investigaciones en Didáctica de \\ las Ciencias Naturales y la Matemática (CeFIEC), ARGENTINA
}

Received 28 July $2020 \cdot$ Accepted 26 May 2021

\begin{abstract}
This article focuses on the integration of argumentation and digital technologies in science teacher education. We present theoretical reflections, results of empirical research, and description of innovative experiences with pre- and in-service biology teachers. Regarding argumentation, we analyse what defending a claim in science entails for teachers, the teaching strategies they (would) use in the classroom in relation to argumentation, the relevance that they attribute to the performance of different tasks for arguing, the subject content where argumentation fits more suitably, and the reasons they would consider in favour of arguing in science classes. For the analysis of educational practices that involve use of technologies, we adopt a perspective that looks at their complexity and recognises teachers as their creative authors. We discuss the way in which teachers (would) use technologies in their practice, their expectations around this, and the foreseen results with students. Finally, we examine three innovative educational experiences already implemented, using argument maps, web-based inquiry, and a digital game. We look into the possibilities that these technological resources offer for teachers to analyse the argumentation levels reached by their students.
\end{abstract}

Keywords: argumentation, digital technologies, pre-service teachers, in-service teachers

\section{INTRODUCTION}

This article focuses on the integration of two salient research lines in didactics of science-argumentation and digital technologies- in science teacher education. We present and discuss results obtained over five years by our research group EDUCEVA with science teachers in Argentina.

Argumentation is recognised as a key linguistic and cognitive process in learning due to the fact that its semiotic properties turn this intellectual and social activity into an exceptional mediation resource in knowledge construction (van Eemeren, Grootendorst, \& Snoeck Henkemans, 2002). Argumentation-based teaching practices thus connect to pedagogies hinging on the epistemic function of disciplinary discourse, and move away from transmission-based conceptions of education. However, a journal content analysis on trends on argumentation research in science education has found that researchers have prioritised the linguistic aspects of argumentation more than its epistemic aspects (Erduran, Ozdem, \& Park, 2015).

In the specific field of science teaching, argumentation favours students' access to cognitive and metacognitive processes in scientific modelling, promotes the development and understanding of inferential and discursive skills in science, contributes to the achievement of students' scientific literacy, favours enculturation in "authentic" practices based on criteria for knowledge evaluation, and develops model-based scientific reasoning and critical thinking (JiménezAleixandre \& Erduran, 2008).

We acknowledge that argumentation is a polysemic concept, inspected with very diverse theoretical frameworks. In this way -and only to browse some authors cited over this chapter- Plantin (1998) centres 


\section{Contribution to the literature}

- The article focuses on the integration of two salient research lines in didactics of science -argumentation and digital technologies- in science teacher education.

- The paper reports different meanings and practices that teachers associate with the inclusion of argumentation and ICT in science classes.

- The study describes teaching experiences incorporating technological resources to encourage and scaffold argumentation.

the study of argumentation in debate between proponents and opponents, van Eemeren et al. (2002) focus on the resolution of differences of opinions among groups of people, and Jiménez-Aleixandre (2010) elaborates on the assessment of claims in the light of evidence.

In the study of "school scientific argumentation" from the perspective of didactics of science, AdúrizBravo (2014) lists three reasons given as justification of the importance of introducing argumentation in science teaching practices. In the first place, learning how to argue can be considered a central process in order to learn to think and construct new knowledge. Secondly, incorporating a scientific practice like argumentation is deemed to contribute to the construction of a view on science in line with contributions of the philosophy and history of science. Finally, the role of argumentation in scientific literacy is underlined: it fosters students' participation in socio-scientific debates.

In relation to the first two reasons to include argumentation, the role of teachers would be providing critical feedback to the arguments developed by students and managing "knowledge under construction" in didactical activities. Teachers would guide students towards the stabilised assertions and procedures accepted in expert communities within an area of study (Buty \& Plantin, 2008). As regards the third reason, teachers should take into account the difficulties involved in integrating different perspectives and references in socio-scientific debate by designing activities directed to scaffolding students' critical assessment of opposing views on a topic (JiménezAleixandre, 2010).

\section{ARGUMENTATION IN SCIENCE TEACHER EDUCATION}

Pioneering research on this topic highlighted the importance of introducing argumentation practices in teacher education programmes from the very beginning and over prolonged periods of time. Didactical interventions focused on ways to facilitate teachers' incorporation of argumentative practices in their classes and developed analytical frameworks to assess the quality of the arguments produced (Erduran, Simon, \& Osborne, 2004; Simon, Erduran, \& Osborne, 2006). Such inquiries have led to the design of materials and instances of pre-service training for science teachers that have achieved improvements in their teaching of argumentation (Erduran, Ardac, \& Yakmaci-Guzel, 2006). Likewise, in more recent years, we found research focused on content or specific teaching strategies and on the construction of arguments by future teachers (Kaya, 2013; Ozdem et al., 2013) and investigations that target both argumentative skills and teachers' pedagogical content knowledge of in-service and future teachers around argumentation (McNeill \& Knight, 2013; McNeill et al., 2016; Vieira et al., 2015; Wang \& Buck, 2016; Zhao et al., 2021). These latter studies highlight the difficulty of teachers to understand arguments and develop different pedagogical strategies to promote argumentation in science classes. In addition, they present possible recommendations and solutions adapted to each context of study.

In the Ibero-American context, we found research focused on the design of argumentation-based classes, studies that approach the conceptions and preparation of teachers to address argumentation in their classes, and evaluations of the impact of teacher training programmes on the development of argumentative competencies.

Jiménez-Aleixandre and her team have conducted extensive research on argumentative processes in science classes. Jiménez-Aleixandre (2008) proposes a model for the design of argumentation learning environments based on six main issues: role of students, role of teacher, curriculum, assessment, metacognition and communication approach. Among the contributions to the field of teacher training, we can highlight the design of didactical resources for the introduction of argumentation and the use of evidence in science classes, from a socioconstructivist perspective and with the idea of forming small communities of practice (JiménezAleixandre et al., 2009).

Regarding the second line of work, Archila (2014) investigated the preparation of future chemistry teachers to promote argumentation in their classes. He found that future teachers would be interested in having students discuss diverse points of view, but they do not have a clear idea on how they could carry out such discussions. In a similar study, but with a quantitative perspective and oriented to pre-service teachers' understanding of argumentation around socio-scientific issues on energy, Martín Gámez and Erduran (2018) found that pre- 
service teachers had difficulty in understanding arguments and in devising different pedagogical strategies to promote argumentation in classroom. Specifically, they did not understand the role and meaning of warrants in scientific arguments, and their understanding of the use of different kinds of strategies was limited to debates, open discussions and experiments.

Research involving the design and implementation of training programmes includes diverse strategies. In the case of Cebrián-Robles, Franco Mariscal, and BlancoLópez (2018), the authors asked prospective teachers to identify the elements of arguments in order to design assessment rubrics, and included peer assessment during evaluation with and without rubrics. The conclusions show that it is possible to improve the argumentative processes of future teachers, especially with regard to the construction of arguments, but that it is necessary to deepen the notion of refutation of ideas among students and pay more attention to the scientific knowledge involved in the tasks of argumentation. Finally, the training proposal by García-Ruiz, Hierrezuelo-Osorio, and Lupión-Cobos (2019) focuses on the promotion of argumentative skills on global climate change through a software that creates online collaborative annotations. The preliminary results presented by the authors highlight the value of the experience for the development of critical thinking. However, the percentage of teachers who identify the value of argumentation for scientific literacy and its contribution to the epistemology of science is low. In addition, teachers state that they consider that the greatest difficulty in teaching argumentation lies in the low argumentative level of their students.

In the Argentinian context, we want to highlight research centred on the inclusion of argumentative practices in pre-service science teacher education. Such research has dealt with a model of "school scientific argumentation" as an analytic tool to study how teachers argue, linking the teaching of argumentation with the nature of science (Adúriz-Bravo, 2011). There are also relevant works analysing both the importance of argumentation within the community of science researchers and naive conceptions that teachers tend to have on such regard. Based on that, some authors propose developing teacher training that considers the nature of argumentation that takes place in science in order to construct less stereotyped views of scientific reasoning and to recognise the social character of knowledge generation (Islas, Stipcich, \& Domínguez, 2006; Islas, Sgro, \& Pesa, 2009). Finally, research conducted in our group has focused on teachers' conceptions and practices with respect to argumentation processes that take place in contexts enriched with Information and Communication Technology (ICT).

\section{WHAT WE MEAN BY “TECHNOLOGIES”}

From a sociocultural perspective, technologies can be considered cultural tools mediating human action. Wertsch (1998) states that human beings act upon nature and modify it through the creation of tools that enable them to have certain control over their environment but, at the same time, condition their conceptualisation of and their action on it. In turn, taking Pierre Lévy (1993) as reference, we can consider that all thinking processes are characterised by the involvement of language, information and intellectual strategies learnt within the framework of a culture, through interactions with others and the use of technological tools in this broad sense. In summary, we could state that cognition is the result of complex networks in which human, biological and technological factors interact, in a way that a person not belonging to a community (of other people and means) could not "think". In this sense, even though a person may be alone at a certain time solving a problem, when doing so, they use different elements available in their sociocultural context, such as concepts, cognitive strategies, ways of reasoning, material and symbolic tools, etc. (Salomon, 2001; Werstch, 1998). Therefore, production of knowledge is not independent from the technologies that are used, but rather the result of an interactive process (Borba \& Villarreal, 2005).

We are particularly interested in looking at the place occupied by ICT, which is a set of cultural tools that modify the ways in which we gain access to and produce knowledge (Dede, 2007). Therefore, ICT becomes means for learning due to the fact that it can create new scenarios for interactions, virtual spaces in which students can not only have access to information, but also share, question, problematise, i.e., learn. Specifically, within the field of science teaching, ICT scaffolds the learning of scientific competencies such as formulation of hypotheses or predictions, interpretation of results, and construction of arguments (Linn, 2003). In this way, if we conceive that technologies offer a space for thinking and constructing ideas in science, it is essential to inspect how integration of these resources is promoted in teacher education.

Concerning the incorporation of ICT in teacher training programmes, Ertmer and Ottenbreit-Leftwich (2010) propose that it should be based on three principles: ICT should be incorporated crosswise, and not via specific courses; ICT should be taught contextually, in relation to concrete problems connected to subject matter; and finally, teachers participating in the training activities should experience the innovative characteristics of technology in their own learning processes. These ideas can be expanded with those of Sancho Gil and Padilla Petry (2016), who highlight the need for teachers to have formative opportunities for: understanding the dimensions of their task in society, developing skills enabling them to establish productive 
learning relations with their students, thinking alternatives to the traditional forms of teaching, analysing the consequences of the changes generated by ICT in the ways of creating, representing, storing and accessing knowledge. Er and Kim (2017) also stress the need for teachers to experience teaching and learning with technologies within the framework of their training, encouraging them to participate in communities of practice and collaboratively design educational resources. These experiences provide opportunities to reflect on teaching and on teachers' pedagogical belief system.

In the case of Argentina, in pre-service teacher education, the nation-wide recommendations drafted by the Ministry of Education and the mixed commission called ANFHE-CUCEN (Spanish acronym for the National Association of Schools of Humanities and Education and the University Council of Exact and Natural Sciences) strongly suggested the development of training actions mediated by ICT in the teaching of scientific disciplines (ANFHE-CUCEN, 2011; Ministry of Education of Argentina, 2012). In relation to teacher training courses offered in our country since the 1990s, different educational experiences and policies have been implemented, starting from technological upgrading programmes for schools accompanied by teacher training proposals (Landau, Serra, \& Gruschetsky, 2007). In turn, as reverberation of the international movement based on the 1-to-1 (one laptop per child) model, in 2010 the Ministry of Education of Argentina developed an equipping programme known as "Conectar Igualdad" (Connecting Equality), focused on the distribution of netbooks to teachers and students in state secondary schools and in institutes for teacher education all over the country. It was also accompanied by teacher training proposals (Lugo \& Kelly, 2011).

Implementation of these equipping programmes in Ibero-America has brought up a number of academic publications directed to knowing the impact of the presence of technologies in the classroom on educational practices. However, even though access to technologies constitutes a necessary condition for technological literacy, this cannot be reached with their mere presence in the classroom. Authors agree on the fact that the key to promote teaching innovation lies on the didactical strategies implemented for the use of technologies, and not on their availability (Cuban, Kirkpatrick, \& Peck, 2001; Lawrence \& Tar, 2018; Turgut \& Aslan, 2021). It is from this epistemological perspective that we have researched into the relations established between ICT and science teaching practices, including argumentation.

Teaching practices are social, and determined by the historical, sociocultural and institutional context in which they take place. Thus, they have pedagogical, political, ethical and intentional character (Jackson, 1986). In this sense, science teaching entails being responsible for distinct social practices configured on decisions that must be taken in contexts characterised by uncertainty and urgency, which require displaying a wide range of abilities and knowledge (Perrenoud, 2004). According to this view, the availability of technologies in the classroom can constitute an opportunity for promoting reflection on the teaching profession and for questioning the established practices.

The relationship between the availability of technologies and teaching practices has been the subject of various research studies. On the one hand, from quantitative research perspectives, several correlational studies have been conducted to analyse how teachers use technology and which variables are better predictors of each type of use. In this sense, Uslu and Usluel (2019) proposed a conceptual framework that identifies three types of educational ICT use: ICT use for motivating students, delivering content, reviewing the lesson; ICT use for promoting student searching and processing information; ICT use for accessing resources, preparing lesson materials. In turn, the authors also identified moments in which ICT could be integrated in an educational way: ICT use before teaching, ICT use for organising teaching and ICT use for enhancing learning. These last typologies are valid for studying how both teachers and students use ICT.

In turn, Coll, Mauri, and Onrubia (2008) distinguish five types of use(rs) of ICT considering dimensions of educational practice and aspects of the technological tools. Those five types refer to ICT as the following instruments: 1. mediators of the relations between students and learning content, 2. mediators of the relations between teachers and teaching content, 3 . mediators of the relations between teachers and students or within the student group, 4. mediators of the joint activity performed by teachers and students during the execution of learning activities, 5. configurators of the learning environments. Finally, Light and Pierson (2013), in their research into the changes and continuities in the practices adopted by teachers from San Luis (Argentina) after "Conectar Igualdad", found out that the presence of netbooks re-configures classroom and school dynamics in different ways. They recognised practices incorporating technologies in a gradient ranging from instrumentalist uses to the generation of entirely new classroom environments.

On the other hand, since the arrival of technologies, how teachers' practices are modified has been studied. In a first stage, teachers seek to adapt/adjust the teaching strategies they normally use in their classrooms to incorporate technologies, which also conditions the type of technology they decide to incorporate (Inan et al., 2010; Tondeur et al., 2017). However, as technologies are established as permanent resources in classrooms, new teaching practices, more student-centered, are deployed, favouring the development of their autonomy. In particular, for science teaching, it is observed that ICT 
enhances project-based learning and problem-based learning (Zheng et al., 2016).

Finally, the relationship between teaching practices and teacher training proposals connected with the 1-to-1 model has been studied. Several authors found that training efforts dissociated from classroom practices cannot modify them; as a consequence, devices end up being underused (Tondeur et al., 2017; Fernandes, Rodrigues, \& Ferreira, 2020). Whereas when teachers have positive experiences with technologies, either due to the incorporation of ICT in their own classroom or indirectly through their colleagues, they are able to see themselves as facilitators (Er \& Kim 2017; Ertmer \& Glazewski, 2015; Tondeur et al., 2020). So, thinking about teaching models that incorporate technologies constitutes an opportunity to re-examine teachers' understanding of science teaching, assess the potential that technologies have as cognitive tools, and explore ways in which they could support learning.

\section{RESEARCH QUESTIONS}

a) What are the conceptions about argumentation held by science teachers from Córdoba (Argentina)? What argumentative practices do they report to carry out in their classes?

b) What are the conceptions about ICT science teachers from Córdoba (Argentina) have? What practices with ICT do they claim to perform in their classes?

c) What potentialities and difficulties are found in the development of school scientific argumentation enriched by digital technologies in the framework of didactical proposals designed in communities of practice integrated by teachers and researchers?

\section{METHODOLOGY}

The present study on science teachers' ideas and practices with argumentation and ICT was conducted from an essentially phenomenographic perspective. This approach starts from the premise that people perceive, conceptualise and understand their experiences -and the dimensions of which they are made- in qualitatively different ways (Marton, 1981).

For data collection, a semi-structured questionnaire was designed, including questions about cadastral aspects (gender, age, degree, length of service as teachers, availability of technology in the educational institution in which they carry out their practices), six items related to argumentation, and five items linked to ICT. For instrument development, we took into account the following authors: Adúriz-Bravo (2014), Coll (2009), and Jimenez-Aleixandre (2008). With respect to argumentation, the following aspects were enquired: a) what does defending a point of view in natural sciences entail for teachers (closed-ended question in which more than one option could be chosen); b) the teaching devices used in the classroom by teachers and their relation with argumentation (closed-ended question); c) the importance that teachers attribute to the performance of different tasks linked to argumentation in their classes (closed-ended question); d) whether teachers consider that there are topics with which developing argumentation is more feasible (open-ended question); e) the strengths attributed to the teaching of argumentation in science classes (open-ended question); and $\mathrm{f}$ ) the difficulties encountered around the possibility of arguing in science classes (open-ended question). Regarding ICT, the questions designed focused on two dimensions: a) advantages and disadvantages of having ICT available in the classroom; and b) ICT integration in their educational practices.

The designed instrument was reviewed by experts, and a pilot test was conducted with five in-service and 10 pre-service teachers that were not part of the final study sample.

Such instrument was applied to 27 students in the degree of biology teaching at the Universidad Nacional de Córdoba (Argentina) who had already completed their teaching practices in schools (of an average age of 28 years, with a minimum age of 21 and a maximum age of 42), and to 51 in-service teachers belonging to 16 state secondary schools in the city of Córdoba (of an average age of 47 years, with a minimum age of 29 and a maximum age of 62). The in-service teachers had an average of 12 years of teaching experience with a minimum of 3 years and a maximum of 30 . Most of them had science teaching degrees and a minority had science degrees (Biologist, Bachelor in Chemical Sciences, Agricultural Engineer), without formal pedagogical training.

The information collected was interpreted on the basis of the theoretical categories proposed by AdúrizBravo (2014), Jiménez-Aleixandre (2008), and Tondeur et al. (2020). Other analytical categories were developed from the regularities found in the corpus of data. The analysis of teachers' ideas and practices was made by taking theoretical constructs as reference and by developing analytical categories according to the regularities observed.

We worked with pre- and in-service teachers in small communities of practice; this enabled the development of original experiences combining argumentation and ICT in science teaching. These communities of practice will be characterised in Section Irruptive Practices Creating New Didactical Paths.

Finally, the procedures used in this study adhere to the tenets of the Declaration of Helsinki and its later amendments, or to comparable ethical standards for research. In this sense, informed consent was obtained from all individual participants included in the study. 


\section{RESULTS AND DISCUSSION}

\section{Science Teachers' Ideas and Practices with Argumentation and ICT}

Our characterisation of the relations of teachers with argumentation and technologies in their practices first deals with their conceptions and perceptions, then moves to their reflections upon the importance accorded to them in their classrooms. Regarding their conceptions about argumentation, both pre- and in-service teachers (more than $70 \%$ ) agree on the idea that defending a claim in science is related to producing evidence that "proves" it. A smaller number of teachers agree to conceptions of argumentation as justifying, with or without trying to convince others (Garcia Romano, 2017; Garcia Romano et al., 2017). These ideas reinforce a conception of argumentation as the use of evidence, but blur into the background what Adúriz-Bravo and Revel Chion (2017) define as the rhetorical component of argumentation.

In relation to technologies, the introduction of ICT in the classrooms is described by pre- and in-service teachers with positive and negative aspects. Pre-service teachers show concern for the fact that technologies provide access to any kind of information that may be unreliable and become a source for students' misconceptions. In turn, both pre- and in-service teachers indicate that the presence of computers in classrooms generates problematic situations, as students lose concentration with games or social networks, and they -as teachers- cannot control such situations. This feeling of "losing control" in the presence of technologies has also been identified by other authors who analysed the implementation of "Conectar Igualdad" (Zanotti \& Arana, 2015). We observe that some in-service teachers associate this loss of concentration with lack of specific planning for using the computer in the classroom.

In the same direction, teachers who are able to make intensive use of ICT identify planning as a key tool to achieve this. Specifically, teachers indicate that, in front of a planned activity incorporating ICT in a non-trivial fashion, students participate even when the technology enables them to access potentially distracting resources such as Facebook, WhatsApp, Instagram, etc. We conclude that teachers adscribe great value to a planning that permits anticipating classroom work with technologies. Such planning requires specific didactical knowledge; for this reason, teachers complain about the lack of teacher training to be able to profit from the potential of these tools. These results coincide with the findings of Inan and Lowther (2010), and Turgut and Aslan (2021), who propose that the incorporation of technology depends on self-confidence and the feeling of preparedness that teachers have to use these tools.

On the other hand, both pre- and in-service teachers indicate that ICT can facilitate subject matter understanding, as it enables incorporating information in different formats; the potential of these resources to incorporate multitextuality is appreciated (as found by Alvarez-Quiroz \& Blanquicett Romero, 2015). In particular, the possibility of enriching study materials with images, videos and simulations is highlighted. Teachers also underline that technologies are friendly tools for students, which should be an invitation to modify the dynamics of their classes in order to present content in a way closer to young people's interests. In this regard, one teacher who was interviewed explains that traditional teaching many times is too far away from young students' cultural practices; she exemplifies this with teachers' stereotypical use of blackboards, which at the end are photographed by students. While the teacher is busy presenting the topic through laborious writing on the blackboard, students can get distracted and lose interest. This interviewed teacher advocates for a practice of collective construction of ideas, which of course commits her to "daring to change classroom dynamics".

The strengths of ICT highlighted by pre- and inservice teachers coincide with findings by other authors (Drossel, Eickelmann, \& Gerick, 2017; Zheng et al., 2016): both groups identify technologies as cultural tools moulding young students' practices and promoting contextualisation of teaching by enabling teaching models aligned with the characteristics of students' local environments and reality. Teachers see ICT as an opportunity to create learning spaces closer to students' interests. In this respect, all pre-service teachers declare they want to move forward and incorporate these resources in their practices. They see themselves as guides and facilitators of learning, and they recognise that technologies open up new opportunities, enable placing students as protagonists, and broaden teaching horizons. In the same line, they indicate that they would need to be more qualified to be able to make the most of these technologies as teaching tools.

So far, we have summarised the conceptions and perceptions about argumentation and technologies in the classroom that we found in teachers. Now we will present how both dimensions (should) take place in the classroom from their point of view. With respect to the way in which they (would) include argumentation in their classes, even though both pre- and in-service teachers mostly agree on a positivistic model that relates defending a claim in science with producing "probatory" evidence, there are differences as regards the teaching devices used in class and the relevance they attribute to the performance of different argumentative tasks. Even though in both groups more than half of the teachers point out that they frequently invoke different points of view in relation to a topic to enable students' argumentation, more than $75 \%$ of in-service teachers indicate that they frequently use books or films containing "information", whereas in the case of preservice teachers, the percentage of frequent use of these 
resources only reaches $40 \%$. As regards the importance ascribed to the performance of varied tasks, the main difference is observed in the value they give to students' searching for different sources of information to justify their answers. While more than $90 \%$ of in-service teachers consider that this activity is important, this percentage barely exceeds $60 \%$ in the case of pre-service teachers.

In relation to the science content in which the development of argumentation in class is more feasible, two different groups of answers can be identified: one group stresses the possibility of doing so with all topics (35\% of in-service teachers and $52 \%$ of pre-service teachers), another group highlights the special relevance of argumentation when teaching socio-scientific issues (around $45 \%$ of both pre- and in-service teachers). In addition, it is important to note that most in-service teachers establish a close link between teaching centred around socio-scientific topics and human health, while in the case of pre-service teachers this link is not present (Garcia Romano, 2017; Garcia Romano et al., 2017).

Concerning the value of teaching argumentation in science classes, we take up the categories proposed by Adúriz-Bravo (2014): teachers justify its inclusion, in the first place, for its contribution to scientific literacy (55\% of in-service teachers and $63 \%$ of pre-service teachers). In the second place, they emphasise the possibility of learning to think (51\% for in-service teachers and $44 \%$ for pre-service teachers). The least chosen reason is the contribution of argumentation to the construction of ideas about science in line with the philosophy and history of science (only 2 active teachers and 3 prospective teachers). So, teachers stress the epistemic dimension of argumentation and its potential for critical thinking (Jiménez-Aleixandre, 2008), but they omit aspects related to the nature of science.

With respect to the difficulties involved in the integration of argumentation in science classes, the prevailing aspect mentioned by in-service teachers is related to the problems that students have in carrying out the tasks proposed (more than $70 \%$ ), while only $22 \%$ of pre-service teachers mention this issue. In the same line, $51 \%$ of pre-service teachers referred to the challenges for them to prepare activities that enable students to argue and the time required for carrying on with this type of classes, whereas among in-service teachers this percentage is reduced to $10 \%$. While we may think that in-service teachers have surely been able to improve their training throughout their career, it is worrying that they cannot identify the challenge of teaching how to argue and teaching through argumentation that has been widely reported in the international literature (Archila, 2014; Cebrián-Robles et al., 2018; Martín Gámez \& Erduran, 2018; Wang \& Buck, 2016; Zhao et al., 2021).
On the other hand, when analysing teachers' didactical activities and the frequency with which ICT is used, we found that the activities that are included frequently by more than half of both groups are those involving search for information on the Internet or writing reports with word processors. These results coincide with a study conducted by Benavides and Pedró (2007) in Ibero-American countries, indicating that cases where ICT is used every day in the classrooms are rare. Therefore, in addition to the frequency of technology use (always, frequently, rarely, never), we analysed the type of activities implemented by teachers involving ICT. We identified four groups of activities: a) those that are incorporated by most ( $50 \%$ or more) preand in-service teachers; $b$ ) those that are incorporated by more than $50 \%$ of in-service teachers but by less than $50 \%$ of pre-service teachers; c) those that are incorporated by some (between 25 and 49\%) teachers; and d) those that are incorporated by very few or nobody ( $24 \%$ or less). Figure 1 compares percentages of pre- and in-service teachers performing the activities in these four groups.

Group "a" includes activities using technology as support to improve the teacher's presentations or "to transmit information", while group " $b$ " includes activities that assign a more active role to students, encouraging information analysis, report writing or activity resolution in web pages. However, technology here is merely another support, given the fact that the activities proposed are the same ones that would be done with paper and pencil, but using computer or mobile technology instead. We would also like to highlight the contrast observed between pre- and in-service teachers as regards "Guided search for information on the Internet", which is proposed by $88 \%$ of the latter and only $37 \%$ of the former. This is related to the different value that teachers assign to students searching for information to justify their answers, which, as it has already been mentioned, is more relevant for in-service teachers. This divergence in practices can be explained by the fact that pre-service teachers show concern for the possibility of having access to "wrong" information, whereas in-service teachers possibly solve this by working in the construction of criteria to search and select.

Activities in groups " $a$ " and " $b$ " are similar to those recorded in the review by Tondeur and colleagues (2017) for teachers who make an incorporation of technology in the classroom that is more teacher-centered. In this modality, technologies are included in an incidental manner or just to enrich the usual practices without modifying them; teachers assign a predominantly passive and receptive role to students. An exception within this group is represented by the task of sharing information in Facebook, proposed by more than $50 \%$ of in-service teachers. We consider that this activity could actually generate different learning opportunities and 


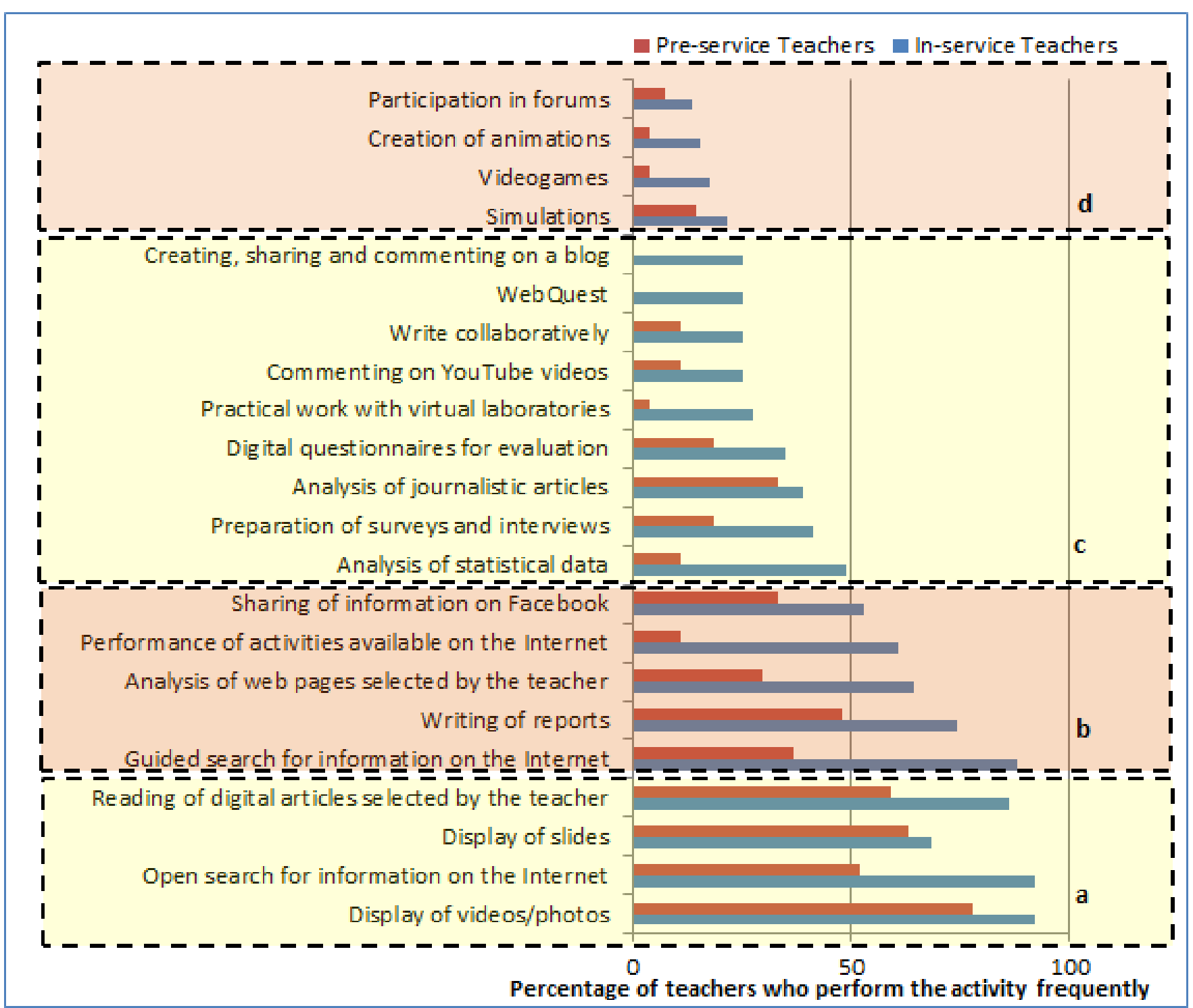

Figure 1. Comparison of percentages of pre-service teachers $(\mathrm{N}=27)$ and in-service teachers $(\mathrm{N}=51)$ who include each of the didactical activities in their classrooms

dynamics. Group " $\mathrm{c}$ " comprises activities requiring greater cognitive commitment by students, through personal production, analysis or argumentation. Finally, group " $\mathrm{d}$ " includes activities that would entail a more creative or innovative use of ICT, which could cause a change in classroom dynamics. Activities included in groups " $\mathrm{c}$ " and " $\mathrm{d}$ " are similar to the teaching practices identified in the review from Tondeur and colleagues (2017), which resulted more student-centered. On the basis of these results, we can summarise that most preand in-service teachers make a weak incorporation of ICT in their classrooms, but practices tending to a more intensive incorporation are beginning to be observed.

\section{Irruptive Practices Creating New Didactical Paths}

Regarding the connection between our topics of study, Schwarz (2018) highlights that although Computer Supported Collaborative Learning (CSCL) theory and research on argumentation and learning look as if they have emerged and developed independently, these two domains are deeply intertwined. In a research that traces the history of these research lines, the author notes that there have been two dominant ways of incorporating argumentation in these settings: Toulmin's structural model and van Eemeren and colleagues' discursive, pragma-dialectic model. Furthermore, he indicates that many of the experiences with ICT and argumentation do not achieve promising results because the software designed primarily focuses on the structural components of argumentation and tends to neglect the social aspect of argumentation, and also because the times and modes of constitution of the communities of practice are not respected.

We are convinced that thinking of teachers as professionals means recognising that it is they who have knowledge and expertise to autonomously design good educational practices. In this respect, one way of promoting changes is by constituting small practice communities in which teachers can assume a more active 
role in their professional development, being responsible for their own learning (Kopcha, 2010). In these communities, teachers jointly explore new ways of teaching with technologies, and support each other as they begin to transform their classroom practices (Higgins \& Spitunik, 2008). So, when teachers participate in this type of experience, they are able to incorporate technologies successfully, and they design paths that foster more equal digital opportunities (Tondeur et al., 2020).

Another aspect to be considered in teacher education is the connection with the curriculum to be taught, given that if teachers realise they can develop the content of their subjects with technologies, they are more prone to use them with their students (Uslu \& Usluel, 2019). Finally, if teachers are able to see technologies as cultural tools that provide autonomy, they will understand that young students are used to virtual worlds and to information management; thus, they will be more willing to leave traditional, ICT-deprived models behind (Seufert, Guggemos, \& Sailer, 2021).

Based on the agreement on the importance of argumentation and ICT for science education, there is a field of work connected with the design of "argumentation environments". These can incorporate technologies aiming at making students participate in constructive and collaborative argumentation, and they can be directed either to peer discussion or to argument modelling (Matuk, 2015). Several science teaching projects have implemented this kind of resources and assessed them by studying the differences between synchronous and asynchronous argumentation, the scaffolding possibilities developed, and the constitution of student groups to achieve co-argumentation. Such projects have resulted in the development of analytical frameworks for studying the argumentative dynamics taking place in different settings (Clark \& Sampson, 2008; Clark et al., 2012; Linn, Clark, \& Slotta, 2003; Quintana et al., 2004). In addition, a number of technological resources (platforms directed to scientific research, virtual laboratories, simulations, etc.) designed in recent years can be seen as technologically enriched environments for argumentation.

But technological resources designed to learn how to argue and to learn science through argumentation have their potential benefits not limited to students. Through these, teachers can regulate their own argumentation and interpret their students' argumentative developments (Clark \& Sampson, 2008). The following paragraphs describe three teaching experiences incorporating technological resources to encourage and scaffold argumentation. We consider that such experiences can contribute to teachers' thinking about new didactical paths.

\section{Debategraph}

Different tools are available for the construction of argument maps; in this first experience we used Debategraph, an open-source resource for collaborative construction of arguments that combines cartography and edition based on the Wiki concept ${ }^{1}$. From the argumentative point of view, the main idea under the resource is representing all relevant points of view within the scope of a problem, and, based on that, solving differences of opinion and searching for solutions (with a conception of argumentation that can be connected to van Eemeren et al., 2002).

We used Debategraph with 37 prospective teachers in the first year of a course on biology education. Teachers were invited to use the tool to present their arguments around problems concerning admission and permanence in university courses in Argentina. We also inquired about their opinion on the positive and negative aspects of this kind of activity through questionnaires and interviews. Among the most relevant results, pre-service biology teachers pointed out that the construction of argument maps enabled them to visualise the arguments of the reference authors and of their classmates, and to negotiate agreements. As for the negative aspects, pre-service teachers indicated that it is difficult to agree on the weight to be ascribed to each argument and to solve differences of opinion with their peers. The search for consensus becomes a positive element of the tool for some students and a negative for others. As Elam and Bertilsson (2003) put forward, such search can entail the exclusion of points of view; an intermediate option -from a more democratic perspective- could include the encouragement of partial consensus through discussion, where dissent has value and, therefore, space is generated to express it. Thus, although this experience showed positive and negative aspects regarding the inclusion of a debating tool, it allowed students to maintain what Schwarz (2018) calls "blended settings" in which computer-supported argumentation is central to promote dialogic and deliberative activities in traditional spaces of higher education.

Argument maps can also become valuable resources for teacher training around socio-scientific topics: guided by a teacher educator, pre- or in-service teachers can learn about the treatment of such topics and reflect on what content and methods could be best when implementing this resource with their own students. As an example, Figure 2 shows an argument map that reconstructs the contributions made by Biology and Chemistry teachers who participated in a teacher training course about genetically modified crops in Argentina. This figure highlights a specific topic within this problem: deforestation.

1 https:/ / debategraph.org/ 


\section{Floods occur}

Biodiversity is reduced

Agronomic practices always expand boundaries
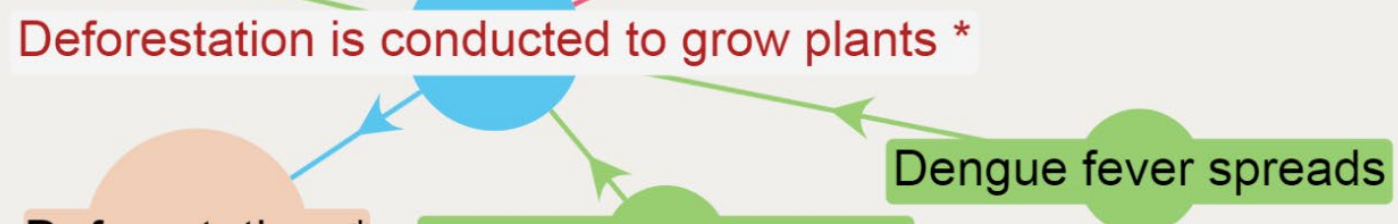

Deforestation * Desertification occurs

Figure 2. Argument map around the topic of deforestation within the framework of genetically modified plant growing in Argentina. This map was created using the DebateGraph web-platform.

Teachers can ask students to construct argument maps taking the debates generated in forums and social networks as reference; in this way, maps can turn into tools to follow up students' progress and metacognition. In addition, maps constructed by one group of students could be analysed by other groups in order to move forward in the understanding of a given topic. Finally, teacher education courses could use previously constructed argument maps in order to analyse the explicit and omitted arguments, and the ways in which ideas are bound together, among other aspects.

\section{WISE (Web-Based Inquiry Science Environment)}

WISE is a digital learning platform for inquiry-based science teaching developed by a team from the University of Berkeley, California that has been used since $1996^{2}$. WISE is organised on the basis of projects requiring students to construct hypotheses, search for information, and examine points of view, among other competencies. For such goals, each project incorporates simulations, tools to make graphs, modelling tools, links to other web pages, etc. (Linn et al., 2003; Romero Ariza \& Quesada Armenteros, 2014). With respect to the argumentative aspect, this environment is essentially based on the conception of argumentation as assessment of claims in the light of evidence (Jiménez-Aleixandre, 2010); the activities give varied priority to persuasion, but the possibility of working collaboratively is included.

A central aspect for teacher education -as Romero Ariza and Quesada Armenteros (2014) point out- is that any professional interested in generating resources for science teaching can add new projects or make proposals to improve the existing.
In our second experience, WISE was used within the framework of pre-service science teacher training; two students from the degree in biology teaching at the Universidad Nacional de Córdoba (Argentina) interested in the topic of argumentation were asked to assess different projects available in the environment through the construction of a series of analysis dimensions. These pre-service teachers were especially concerned about what Bogar (2019) defines as traditional science education, which can lead to a positivistic view of science, which includes clear-cut "truths" and unquestionably accepted results reached from data. The value of this experience lies in the fact that the two prospective teachers were monitored for a full year, which is relatively unusual in the context of this type of research (Schwarz, 2018). As regards the argumentative dimension, participants could characterise both the level of difficulty of each project and the prevailing conception of argumentation; these criteria were used to select the most suitable project for a group of students. After this, they could analyse students' argumentative exchanges through the lens of Toulmin's (1958) ideas. Pre-service teachers developed analysis tools that could be later used to systematically assess other classroom resources. In their analysis, they were able to link the argumentative and technological dimensions when considering their future teaching practices (Mermoud, Ordoñez, \& Garcia Romano, 2017).

\section{PREGUNTIC}

Construction of "good" questions is a central scientific practice (Oliveira, 2010). Based on this, our group developed a digital game aimed at giving students and teachers the possibility of elaborating questions connected with a series of topic categories -

2 https:/ / wise.berkeley.edu/ 
modifiable for each case-, and of playing in computers through the dynamics they choose to implement forming one or more groups, with or without time limit, etc. - and with a configuration that does not require the use of the Internet.

Two instances with this game were organised involving teachers and students from two secondary schools in the city of Córdoba and members of our research group. The first experience was developed in a public secondary school with a population of students from a vulnerable economic background; most of them work informally after school-time. The work was structured in three stages.

In the first stage, 16 students organised in groups, conducted bibliographic research about the lesson topic, formulated questions to play, and analysed them together with their teachers. In a second phase, the game was configured: students chose representative images of the topic and uploaded the questions elaborated for each game category. Finally, groups exchanged the questions formulated, and the game was played. After a joint assessment of the proposal, and taking into account students' perspective, the conclusions reached were that the game was motivating for students, that the stage of the experience in which they had learnt the most was during the formulation of questions, and that the fact of jointly constructing a product that could be adapted to new situations had an additional value for the participating teachers (Pomar et al., 2016).

The second experience was developed in another public school in the city of Córdoba, with students from families with average income (very few of them worked after school-time). Twenty-four students participated in this experience, which was carried out together with one of the teachers who participated in the previous one. A phase involving review by peers was included after the formulation of questions, and audio was recorded while students formulated questions. After analysing the questions posed, we found that students were able, starting from argumentation in small groups, to revise aspects connected with the conceptual content of the lesson and to assess the suitability of the questions for the audience and for the game. Students underlined that the proposal helped them understand the topic more deeply, relate in new ways with ICT, work in groups, and see tasks from a different point of view. We highlight the relevance of the experience in linking the argumentative process with biological content and the opportunity for students to revise their texts and discuss face-to-face in group spaces. Taking into account the notions developed by Plantin (2014), this didactical proposal sought the active participation of students, recovering their voices in argumentative instances, an issue that has not been worked on before in this context.

\section{FINAL CONSIDERATIONS}

Results reported here enable us to recognise different meanings and practices that teachers associate with the inclusion of argumentation and ICT in science classes. The importance of rethinking the ways in which argumentation is incorporated in teacher education in technologically enriched contexts emerges as a conclusion.

We found out that teachers prioritise the idea of arguing as presenting evidence that proves a point of view; even though the persuasive component of argumentation is present, teachers usually push it into the background. This traditional perspective probably arises from the delegitimation suffered by rhetoric at different times in history, while an incipient valorisation of rhetoric would be linked to the value currently attributed to debate in citizenship (Plantin, 2004).

We also recognised two points of tension: 1 . whereas part of teachers take a more inclusive stand with respect to the science topics that can be taught by means of argumentation, many relate argumentation only to socio-scientific issues; 2 . while some teachers propose argumentation as a teacher-centred process, others focus on the possibilities of students learning how to argue.

In relation to teachers' perceptions about the inclusion of technologies, even though some teachers show reservations due to the fear of students getting distracted by them, technologies are generally conceived as cultural tools close to young people's everyday practices. Teachers recognise that ICT gives the opportunity to reformulate their classes, and that such action requires carefully planned proposals enabling anticipation of scenarios. Another potential identified by teachers is that ICT enables them to present content in a multitextual manner, and opens access to different information sources.

Even though most surveyed teachers make a weak incorporation of technologies in their classrooms, we recognised some practices tending to an intensive incorporation enabling to "think with" technologies, where teachers act as facilitators (Borba \& Villarreal, 2005). The small number of teachers who propose a more innovative use of technologies coincides with results obtained by Sancho Gil and Padilla Petry (2016). Therefore, it could be expected that -just as in their caseas time goes by, our subjects will overcome their fears and prejudices and move towards employing ICT in more transformative practices such as the ones described in Section Irruptive Practices Creating New Didactical Paths. On this last regard, based on the analysis of teachers who participated in small practice communities, we observed that their proposals took advantage of ICT potentials to mediate learning processes and foster argumentation practices in the classroom. Following Ertmer (2005), we consider that it is necessary to enable teachers to live positive 
experiences with technologies and to work in collaborative groups arguing around sensible practices.

Concerning the three technological resources described in this article, they provided fruitful argumentation environments. When using them in teacher education, it is crucial that conceptions on argumentation underlying each resource become explicit; we have advocated for a reflective use of these tools with teachers, where they can learn how to argue, but also about the nature of argumentation and the quality of students' arguments.

Teachers' perceptions and practices on ICT-enriched argumentation are complex, with many dimensions to be taken into account. It is our contention that science teacher education around this issue should: include different theoretical frameworks on argumentation, enable teachers to argue and to design activities for their students to argue, propose the analysis of arguments in "natural" teaching contexts, and foster discussion concerning the levels of argumentation that we want to achieve in compulsory science education.

The potential of argumentation in technologymediated environments creates new scenarios for science teacher education that imply mobilisation of their ideas and transformation of their practices. The key to promote innovative didactical activities lies in placing teachers as protagonists -giving to them the space and opportunity to create, innovate and experiment with argumentation in the construction of scientific knowledge in the classroom.

One limitation of our study is related to the analysis of actual teaching practices, since our findings come from data reported by teachers in their responses to questionnaires. We understand that, for a deeper analysis, further research is required to collect information about how teaching practices are developed in the classroom, what challenges arise and how teaching and learning processes take place. In this sense, our research group is developing design-based research (DBR) with in-service and pre-service teachers that will allow us to expand, nuance or confront the results presented here.

Author contributions: All authors have sufficiently contributed to the study, and agreed with the results and conclusions.

Funding: This work was supported by the Agencia Nacional de Promoción Científica y Técnica, Argentina: PICT-2018-1821 and by the Secretaría de Ciencia y Tecnología, Universidad Nacional de Córdoba, Argentina.

Declaration of interest: No conflict of interest is declared by authors.

\section{REFERENCES}

Adúriz-Bravo, A. (2011). Fostering model-based school scientific argumentation among prospective science teachers. US-China Education Review, 8(5), 718-723.
Adúriz-Bravo, A. (2014). Revisiting school scientific argumentation from the perspective of the history and philosophy of science. In M. R. Mathews (Ed.), International handbook of research in history, Philosophy and science teaching (pp. 1443-1472). Springer. https://doi.org/10.1007/978-94-0077654-8_45

Adúriz-Bravo, A., \& Revel Chion, A. (2017). Language, Discourse, Argumentation and Science Education. In K. S. Taber \& B. Akpan (Eds.), Science education (pp. 157-166). SensePublishers. https://doi.org/ 10.1007/978-94-6300-749-8_12

Álvarez-Quiroz, G. B., \& Blanquicett Romero, J. C. (2015). Percepciones de los docentes rurales sobre las TIC en sus prácticas pedagógicas [Perceptions of rural teachers on ICT in their teaching]. Ciencia, Docencia y Tecnología, 26(51), 371-394.

ANFHE-CUCEN (2011). Lineamientos Básicos sobre Formación Docente de Profesores Universitarios [Basic Guidelines on Teacher Training for University Professors]. http://www.anfhe.org.ar/ archivos/lineas_trabajo/documento_comision_mi xta\%20anfhe-cucen.pdf

Archila, P. A. (2014). Are science teachers prepared to promote argumentation? A case study with preservice teachers in Bogotá city. Asia-Pacific Forum on Science Learning and Teaching, 15(1), Article 2.

Benavides, F., \& Pedró, F. (2007). Políticas educativas sobre nuevas tecnologías en los países iberoamericanos. Revista Iberoamericana de Educación, 45, 19-69. https://doi.org/10.35362/ rie 450726

Bogar Y. (2019). Synthesis study on argumentation in science education. International Education Studies, 12(9), 1. https:// doi.org/10.5539/ies.v12n9p1

Borba, M., \& Villarreal, M. (2005). Humans-with-media and the reorganization of mathematical thinking: information and communication technologies, modeling, experimentation and visualization. Springer.

Buty, C., \& Plantin, C. (2008). L'argumentation à l'épreuve de l'énseignement des sciences et viceversa [Argumentation put to the test of science education and vice versa]. In C. Buty \& C. Plantin (Eds.), Argumenter en classe de sciences. Du débat à l'apprentissage (pp. 17-41). Institut National de Recherche Pédagogique.

Cebrián-Robles, D., Franco Mariscal, A. J., \& BlancoLópez, A. (2018). Preservice elementary science teachers' argumentation competence: impact of a training programme. Instructional Science, 46, 789817. https:/ / doi.org/10.1007/s11251-018-9446-4

Clark, D. B., \& Sampson, V. (2008). Assessing dialogic argumentation in online environments to relate structure, grounds, and conceptual quality. Journal 
of Research in Science Teaching, 45(3), 293-321. https://doi.org/10.1002/tea.20216

Clark, D. B., Sampson, V., Chang, H., Zhang, H., Tate, E. D., \& Schwendimann, B. (2012). Research on critique and argumentation from the technology enhanced learning in science center. In M. S. Khine (Ed.), Perspectives on Scientific Argumentation (pp. 157-199). Springer. https://doi.org/10.1007/97894-007-2470-9 9

Coll, C., Mauri, M. T., \& Onrubia, J. (2008). Analyzing actual uses of ICT in formal educational contexts: A socio-cultural approach. Revista Electrónica de Investigación Educativa, 10(1). http:/ / redie.uabc.mx /vol10no1/contents-coll.html

Cuban, L., Kirkpatrick, H., \& Peck, C. (2001). High access and low use of technologies in high school classrooms: Explaining an apparent paradox. American Educational Research Journal, 38(4), 813834. https:// doi.org/10.3102/00028312038004813

Dede, C. (2007). Reinventing the role of information and communications technologies in education. Yearbook of the National Society for the Study of Education, 106(2), 11-38. https://doi.org/10.1111/ j.1744-7984.2007.00113.x

Drossel, K., Eickelmann, B., \& Gerick, J. (2017). Predictors of teachers' use of ICT in school - the relevance of school characteristics, teachers' attitudes and teacher collaboration. Education and Information Technologies, 22(2), 551-573. https:// doi.org/10.1007/s10639-016-9476-y

Elam, M., \& Bertilsson, M. (2003). Consuming, engaging and confronting science. The emerging dimensions of scientific citizenship. European Journal of Social Theory, 6(2), 233-251. https://doi.org/10.1177/ 1368431003006002005

Er, E., \& Kim, C. (2017). Episode-centered guidelines for teacher belief change toward technology integration. Educational Technology Research and Development, 65(4), 1041-1065. https://doi.org/ 10.1007/s1142 3-017-9518-1

Erduran, S., Ardac, D., \& Yakmaci-Guzel, B. (2006). Learning to teach argumentation: Case studies of pre-service secondary science teachers. Eurasia Journal of Mathematics, Science and Technology Education, 2(2), 1-14. https://doi.org/10.12973/ ejmste/75442

Erduran, S., Ozdem, Y., \& Park, J.Y. (2015). Research trends on argumentation in science education: a journal content analysis from 1998-2014. International Journal of STEM Education, 2, 5. https:// doi.org/10.1186/s40594-015-0020-1

Erduran, S., Simon, S., \& Osborne, J. (2004). TAPping into argumentation: Developments in the application of Toulmin's argument pattern for studying science discourse. Science Education, 88(6), 915-933. https:/ / doi.org/10.1002/sce.20012

Ertmer, P. A. (2005). Teacher pedagogical beliefs: The final frontier in our quest for technology integration? Educational Technology Research and Development, 53(4), 25-39. https://doi.org/10.1007/ BF02504683

Ertmer, P. A., \& Glazewski, K. D. (2015). Essentials of PBL implementation: Fostering collaboration, transforming roles, and scaffolding learning. In A. Walker, H. Leary, C. Hmelo-Silver, \& P. A. Ertmer (Eds.), Essential readings in problem-based learning (pp. 89-106). Purdue University Press. https://doi.org/10.2307/j.ctt6wq6fh.12

Ertmer, P. A., \& Ottenbreit-Leftwich, A. T. (2010). Teacher technology change. How knowledge, confidence, beliefs, and culture intersect. Journal of Research on Technology in Education, 42(3), 255-284. https:/ / doi.org/10.1080/15391523.2010.10782551

Fernandes, G. W. R., Rodrigues, A. M., \& Ferreira, C. A. (2020). Professional development and use of digital technologies by science teachers: A review of theoretical frameworks. Research in Science Education, 50, 673-708. https://doi.org/10.1007/ s11165-018-9707-x

Garcia Romano, L. (2017). Concepciones sobre argumentación de futuros docentes de biología [Pre-service Biology Teachers' Conceptions about Argumentation]. Enseñanza de las Ciencias, Número extraordinario, 2335-2341. https://raco.cat/index. php/Ensenanza/article/view/336854

Garcia Romano, L., Condat, M.E., Occelli, M., Masullo, M., \& Valeiras, N. (2017). Some conceptions about argumentation of in-service science teachers in Córdoba (Argentina). In O. Finlayson, E. McLoughlin, S. Erduran \& P. Childs (Eds.), Research, practice and collaboration in science education (Proceedings of ESERA 2017) (pp. 945-951). Dublin, Ireland: Dublin City University https://www. esera.org/publications/esera-conferenceproceedings/esera-2017

García-Ruiz, C., Hierrezuelo-Osorio, J., \& Lupión-Cobos, T. (2019). Applying argumentation in primary preservice teacher education. A teaching-learning sequence using collaborative video annotations. In O. Levrini \& G. Tasquier (Eds.), Electronic Proceedings of the ESERA 2019 Conference: The Beauty and Pleasure of Understanding: Engaging with Contemporary Challenges Through Science Education (pp. 1409-1418). Bologna: ALMA MATER STUDIORUM - University of Bologna. https://www.esera.org/publications/eseraconference-proceedings/esera-2019

Higgins, T. E., \& Spitunik, M. W. (2008). Supporting teachers' use of technology in science instruction through professional development: A literature 
review. Journal of Science Education and Technology, 17, 511-521. https://doi.org/10.1007/s10956-0089118-2

Inan, F. A., \& Lowther, D. L. (2010). Laptops in the K-12 classrooms: Exploring factors impacting instructional use. Computers \& Education, 55(3), 937944.

https:// doi.org/10.1016/j.compedu.2010.04.004

Inan, F. A., Lowther, D. L., Ross, S. M., \& Strahl, J. D. (2010). Pattern of classroom activities during students' use of computers: relations between instructional strategies and computer applications. Teaching and Teacher Education, 26(3), 540-546. https:// doi.org/10.1016/j.tate.2009.06.017

Islas, S. M., Sgro, M. R., \& Pesa, M. A. (2009). La argumentación en la comunidad científica y en la formación de profesores de física [Argumentation in scientific community and in Physics teachers' education]. Ciência E Educação, 15(2), 291-304. https:/ / doi.org/10.1590/S1516-

73132009000200004

Islas, S., Stipcich, S., \& Domínguez, A. (2006). El lugar de la argumentación en la formación de profesores de ciencias [The place of argumentation in the training of science teachers]. Revista Chilena de Educación Científica, 5(1), 67-74.

Jackson, P. (1986). The practice of teaching. Teachers College Press.

Jiménez-Aleixandre, M. P. (2008). Designing argumentation learning Environments. In S. Erduran \& M. P. Jiménez-Aleixandre (Eds.), Argumentation in Science Education. Perspectives from Classroom-Based Research (pp. 91-115). Springer. https:/ / doi.org/10.1007/978-1-4020-6670-2_5

Jiménez-Aleixandre, M. P. (2010). Diez ideas clave. Competencias en argumentación y uso de pruebas [Ten key ideas. Competences in argumentation and use of evidence]. Grao.

Jiménez-Aleixandre, M. P., \& Erduran, S. (2008). Argumentation in science Education: An Overview. In S. Erduran \& M. P. JiménezAleixandre (Eds.), Argumentation in Science Education. Perspectives from Classroom-Based Research (pp. 3-27). Springer. https:// doi.org/10.1007/9781-4020-6670-2_1

Jiménez-Aleixandre, M. P., Gallástegui Otero, J. R., Santamaría, F. E., \& Puig Mauriz, B. (2009). Resources for introducing argumentation and the use of evidence in science classrooms. Santiago de Compostela: Danú. www.rodausc.eu

Kaya, E. (2013). Argumentation practices in classroom: Pre-service teachers' conceptual understanding of chemical equilibrium. International Journal of Science Education, 35(7), 1139-1158. https://doi.org/ $10.1080 / 09500693.2013 .770935$
Kopcha, T. J. (2010). A systems-based approach to technology integration using mentoring and communities of practice. Educational Technology Research and Development, 58(2), 175-190. https:// doi.org/10.1007/s11423-008-9095-4

Landau, M., Serra, J., \& Gruschetsky, M. (2007). Acceso universal a la alfabetización digital. Políticas, problemas $y$ desafios en el contexto argentino (La Educación en Debate 5) [Universal access to digital literacy. Policies, problems and challenges in the Argentine context (Education in Debate 5)]. DiNIECE, Ministerio de Educación, Ciencia y Tecnología. http:/ / www.bnm.me.gov.ar/giga1/documentos/ EL000984.pdf

Lawrence, J. E., \& Tar, U. A. (2018). Factors that influence teachers' adoption and integration of ICT in teaching/learning process. Educational Media International, 55(1), 79-105. https:// doi.org/10.1080 /09523987.2018.1439712

Lévy, P. (1993). As tecnologías da inteligência. O futuro do pensamento na era da informática [Intelligence technologies. The future of thinking in the computer age]. Editora 34.

Light, D., \& Pierson, E. (2013). Changing classroom practices through a one-to-one laptop program in rural Argentina: Experiences of schools in San Luis. International Journal for E-Learning Security, 3(1/2), 236-243. https:// doi.org/10.20533/ijels.2046.4568. 2013.0030

Linn, M. C. (2003). Technology and science education: starting points, research programs, and trends. International Journal of Science Education, 25(6), 727758. https:// doi.org/10.1080/09500690305017

Linn, M., Clark, D., \& Slotta, J. D. (2003). WISE design for knowledge integration. Science Education, 87(4), 517-538. https:/ / doi.org/10.1002/sce.10086

Lugo, M. T., \& Kelly, V. (2011). El modelo 1 a 1: un compromiso por la calidad y la igualdad educativas. La gestión de las TIC en la escuela secundaria: nuevos formatos institucionales [The 1 to 1 model: a commitment to educational quality and equality. ICT management in secondary school: new institutional formats]. Ministerio de Educación de la Nación.

Martín-Gámez, C., \& Erduran, S. (2018). Understanding argumentation about socio-scientific issues on energy: a quantitative study with primary preservice teachers in Spain. Research in Science $\mathcal{E}$ Technological Education, 36(4), 463-483. https:/ / doi.org/10.1080/02635143.2018.1427568

Marton, F. (1981). Phenomenography - describing conceptions of the world around us. Instructional Science, 10, 177-200. https://doi.org/10.1007/ BF00132516 
Matuk, C. (2015). Argumentation environments. In R. Gunstone (Ed.), Encyclopedia of science education (pp. 59-63). Springer. https://doi.org/10.1007/978-94007-2150-0_71

McNeill, K. L., \& Knight, A. M. (2013). Teachers' pedagogical content knowledge of scientific argumentation: The impact of professional development on K-12 teachers. Science Education, 97(6), 936-972. https:// doi.org/10.1002/sce.21081

McNeill, K. L., González-Howard, M., Katsh-Singer, R. \& Loper, S. (2016). Pedagogical content knowledge of argumentation: Using classroom contexts to assess high-quality PCK rather than pseudoargumentation. Journal of Research in Science Teaching, 53, 261-290. https://doi.org/10.1002/ tea. 21252

Mermoud, S. R., Ordoñez, C., \& Garcia Romano, L. (2017). Potencialidades de un entorno virtual de aprendizaje para argumentar en clases de ciencias en la escuela secundaria [Potentialities of a virtual learning environment to support students' argumentation in science classes at secondary school]. Revista Eureka sobre Enseñanza y Divulgación de las Ciencias, 14(3), 587-600. https://doi.org/ 10.25267/Rev_Eureka_ensen_divulg_cienc.2017.v1 4.13.06

Ministry of Education of Argentina. (2012). Plan nacional de educación obligatoria y formación docente (Resolución CFE No 188/12 - 5 de diciembre de 2012) [National plan for compulsory education and teacher training (CFE Resolution No. 188/12 December 5, 2012)]. http://www.me.gov.ar/ consejo/resoluciones/res12/188-12_01_01.pdf

Oliveira, A. W. (2010). Improving teacher questioning in science inquiry discussions through professional development. Journal of Research in Science Teaching, 47(4), 422-453. https:/ / doi.org/10.1002/tea.20345

Ozdem, Y., Ertepinar, H., Cakiroglu, J., \& Erduran, E. (2013). The nature of pre-service science teachers' argumentation in inquiry-oriented laboratory context. International Journal of Science Education, 35(15), 2559-2586. https://doi.org/10.1080/ 09500693.2011.611835

Perrenoud, P. (2004). Desarrollar la práctica reflexiva en el oficio de enseñar. Grao.

Plantin, C. (1998). La argumentación [The argumentation]. Ariel.

Plantin, C. (2004). Pensar el debate. Revista Signos, 37(55), 121-129. https:/ / doi.org/10.4067/S0718-093420040 05500010

Plantin, C. (2014). Lengua, argumentación y aprendizajes escolares [Language, argumentation and learning in the school]. Tecné, Episteme $y$ Didaxis, 36, 95-114. https://doi.org/10.17227/ 01213814.36ted95.114
Pomar, S., González, J.M., Ibáñez, F., Tello, N., Biber, P., Occelli, M., \& Garcia Romano, L. (2016). PREGUNTIC: un juego digital para la enseñanza de las ciencias naturales en la escuela secundaria [PREGUNTIC: A Digital Game for Natural Science Teaching in Secondary Schools]. In Ferreyra. H.A. (Ed.), El currículum de Ciencias Naturales de la Educación Secundaria: retos y desafios de cara al futuro: Dossier. Córdoba: EDUCC http:/ / pa.bibdigital.uccor.edu.ar/873/

Quintana, C., Reiser, B. J., Davis, E. A., Krajcik, J., Fretz, E., Golan Duncan, R., Kyza, E., Edelson, D., \& Soloway, E. (2004). A Scaffolding Design Framework for Software to Support Science Inquiry. The Journal of the Learning Sciences, 13(3), 337-386.

https://doi.org/10.1207/s15327809jls1303_4

Romero Ariza, M., \& Quesada Armenteros, A. (2014). Nuevas tecnologías y aprendizaje significativo de las ciencias [ICT and meaningful science learning]. Enseñanza de las Ciencias, 32(1), 101-115. https:// doi.org/10.5565/rev/ensciencias.433

Salomon, G. (2001). Distributed cognitions: Psychological and educational considerations. Cambridge University Press.

Sancho Gil, J., \& Padilla Petry, P. (2016). Promoting digital competence in secondary education: are schools there? Insights from a case study. Journal of New Approaches in Educational Research, 5(1), 57-63. https:/ / doi.org/10.7821/naer.2016.1.157

Schwarz, B. B. (2018). Computer-Supported Argumentation and learning. In F. Fischer, C. E. Hmelo-Silver, S. R. Goldman, \& P. Reimann (Ed.), International Handbook of the Learning Sciences (pp. 318-329). Routledge. Taylor \& Francis. https:/ / doi.org/10.4324/9781315617572-31

Seufert, S., Guggemos, J., \& Sailer, M. (2021). Technology-related knowledge, skills, and attitudes of pre- and in-service teachers: The current situation and emerging trends. Computers in Human Behavior, 115, 106552. https://doi.org/ 10.1016/j.chb.2020.106552

Simon, S., Erduran, S., \& Osborne, J. (2006). Learning to teach argumentation: Research and development in the science classroom. International Journal of Science Education, 28(2\&3), 235-260. https://doi.org/ $10.1080 / 09500690500336957$

Tondeur, J., Scherer, R., Siddiq, F., \& Baran, E. (2020). Enhancing pre-service teachers' technological pedagogical content knowledge (TPACK): A mixed-method study. Educational Technology Research E Development, 68(1), 319-343. https:/ / doi.org/10.1007/s11423-019-09692-1

Tondeur, J., van Braak, J., Ertmer, P. A., \& OttenbreitLeftwich, A. (2017). Understanding the relationship 
between teachers' pedagogical beliefs and technology use in education: a systematic review of qualitative evidence. Educational Technology Research and Development 65(3), 555-575. https:/ / doi.org/10.1007/s11423-016-9481-2

Toulmin, S. (1958). The uses of argument. Cambridge University Press.

Turgut, Y. E., \& Aslan, A. (2021). Factors affecting ICT integration in TURKISH education: a systematic review. Education and Information Technologies, 1-24. https:/ / doi.org/10.1007/s10639-021-10441-2

Uslu, N. A., \& Usluel, Y. K. (2019). Predicting technology integration based on a conceptual framework for ICT use in education. Technology, Pedagogy and Education, 28(5), 517-531. https:/ / doi.org/10.1080/ 1475939X.2019.1668293

van Eemeren, F., Grootendorst, R., \& Snoeck Henkemans, F. (2002). Argumentation. Analysis, evaluation, presentation. Lawrence Erlbaum.

Vieira, R. D., da Rocha Bernardo, J. R., Evagorou, M., \& Florentino de Melo, V. (2015). Argumentation in science teacher education: The simulated jury as a resource for teaching and learning. International Journal of Science Education, 37(7), 1113-1139. https:/ / doi.org/10.1080/09500693.2015.1022623
Wang, J., \& Buck, G. A. (2016) Understanding a high school physics teacher's pedagogical content knowledge of argumentation. Journal of Science Teacher Education, 27(5), 577-604. https://doi.org/ 10.1007/s10972-016-9476-1

Wertsch, J. V. (1998). Mind as action. Oxford University Press. https://doi.org/10.1093/acprof:oso/978019 5117530.001.0001

Zanotti, A., \& Arana, A. (2015). Implementación del Programa Conectar Igualdad en el aglomerado Villa María-Villa Nueva, Córdoba, Argentina [Implementation of the Program Conectar Igualdad in the Villa Maria-Villa Nueva agglomerate, Córdoba, Argentina]. Ciencia, Docencia y Tecnología, 26(50), 120-143.

Zhao, G., Zhao, R., Li, X., Duan, Y., \& Taotao Long (2021). Are preservice science teachers (PSTs) prepared for teaching argumentation? Evidence from a university teacher preparation program in China. Research in Science $\mathcal{E}$ Technological Education. https:/ / doi.org/10.1080/02635143.2021.1872518

Zheng, B., Warschauer, M., Lin, C. H., \& Chang, C. (2016). Learning in one-to-one laptop environments: A meta-analysis and research synthesis. Review of Educational Research, 86(4), 1052-1084.

https:/ / doi.org/10.3102/0034654316628645

\section{http://www.ejmste.com}

